\title{
Endoscopic Findings in Adults with Nasal Obstruction: A case series study
}

\author{
Hassan Myasar Abdulwahid* , Anmar Abdula Jassim* , Islam Ghanim Mahmood*, \\ Raghdan Mohammed Dawood* \\ *Al-Jumhoori Teaching Hospital , Mosul , Iraq \\ Correspondence: altalib52@gmail.com
}

(Ann Coll Med Mosul 2021; 43 (2):123-131).

Received: $28^{\text {th }}$ June 2021; Accepted: $31^{\text {th }}$ August 2021.

\begin{abstract}
Background: The obstruction of the nasal is known as the most distinct disturbing complain of nasal disease and nasal sinus. The nasal obstruction could either be found unilateral (in one nasal cavity), bilateral (in both cavities), intermittent, progressive or persistent. The rhino-scopy (anterior and posterior) provides limited information when compared to nasal endoscopy. In certain cases, the structure which lies under the sight line and the posterior rhino-scopy is not possible. Furthermore, the early diagnosis of many unpleasant lesions will be very difficult unless using nasal endoscopy.

Objectives: This study was designed to identify the real \& precise causes of nasal obstruction in adults \& properly evaluate the condition of nasal cavity ,post nasal space and nasal mucosa by direct vision through nasal endoscopy. and evaluate the value of naso endoscopy in diagnosis of the cause of nasal obstruction.

Methods: This study was conducted to analyze noses related to 75 patients with nasal obstruction who underwent clinical and endoscopic nasal examination for the period from May 2014 to April 2015 in Mosul namely; Al-jumhoori Teaching hospital.

Results: This case series study included 75 patients complaining from nasal obstruction The study include 43 male patients $(57.3 \%)$, and 32 female patients $(42.6 \%)$ with a M:F ratio of (1.3:1). The patients' ages ranged between 15-70 years of age whose mean age was 42.5 years. endoscopic findings for adults patients with nasal obstruction in our study were: congested nasal mucosa $40(53.3 \%)$ patients, septal deviation $26(34.6 \%)$ patients, inferior turbinate hypertrophy $18(24.0 \%)$ patients, pale swollen mucosa with watery nasal secretion $14(18.6 \%)$ patients, bilateral nasal polyposis $10(13.3 \%)$, post nasal drip $10(13.3 \%)$, crustation $8(10.6 \%)$, mucopurulent discharge from middle meatus \& congested mucosa 7 patients $(9.3 \%)$, adenoid hypertrophy 5 patients $(6.6 \%)$, no abnormal findings 4 patients $(5.3 \%)$, bluish tinged mucosa with watery nasal secretion 3 patients $(4.0 \%)$.

Conclusion: Nasal endoscopy includes evaluating the passages of the nasal cavity and the nasal sinus, and post nasal space using a magnified high-quality view and serves as an objective diagnostic tool in the evaluating of nasal mucosa, sinonasal anatomy, nasal cavity, and post nasal space pathology.

In this study, nasal endoscopy is recommended in cases where patients complain of obstruction in the nasal specifically when anterior and posterior rhino-scopic examinations do not succeed in diagnosing causes of nasal obstruction
\end{abstract}

Keywords: Nasal obstruction, allergic rhinitis, nasal endoscope, septal deviation .

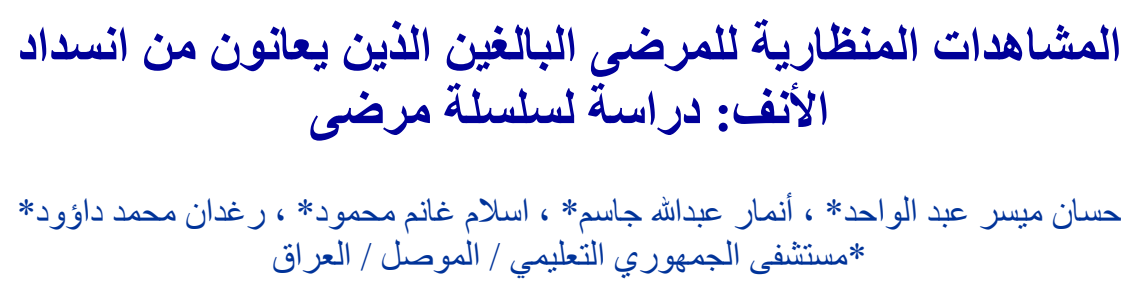

الخلاصة

الهدف: تم تصميم هذه الدر اسة لتحديد مشاهدات الانف المنظارية الاكثر شيو عا لدى المرضى البالغين والذين يعانون من انسداد

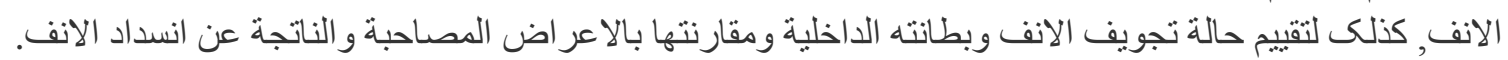


الطرق المستعملة: دراسة لسلسلة مرضى مهنمة بحالة Vo مريضا يعانون من انسداد الانف ممن تم فحصهم سريريا

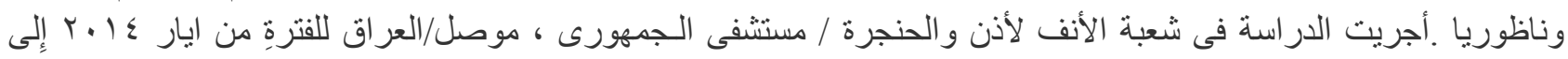

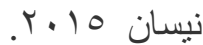

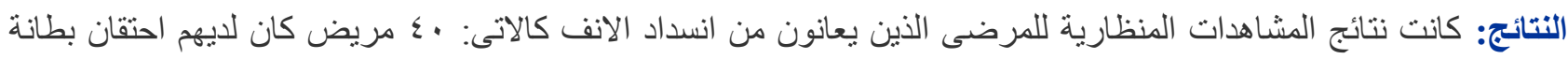

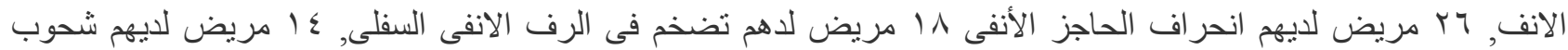

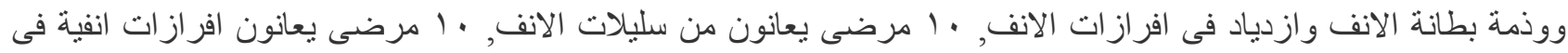

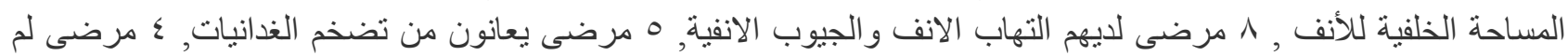

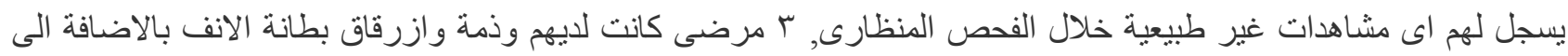

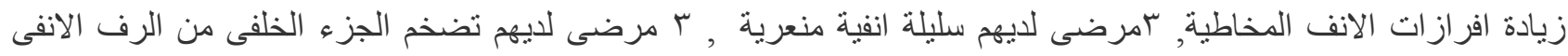

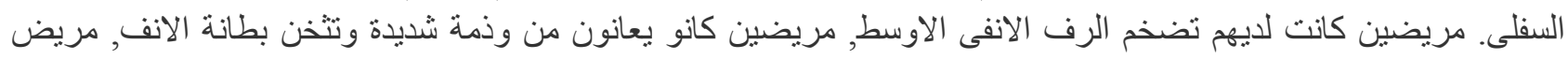

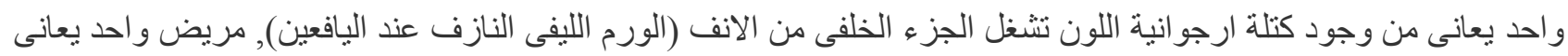

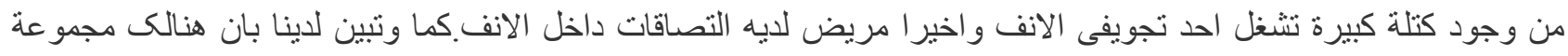

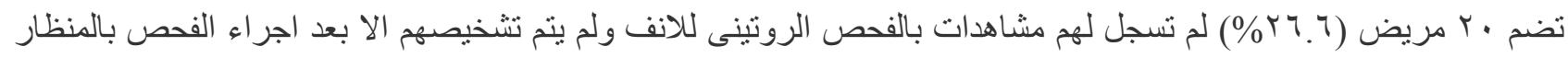

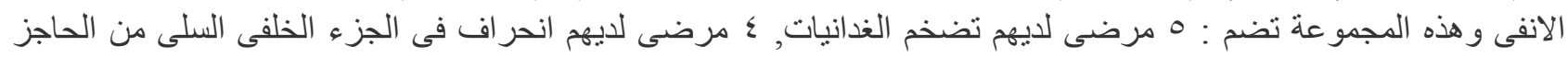

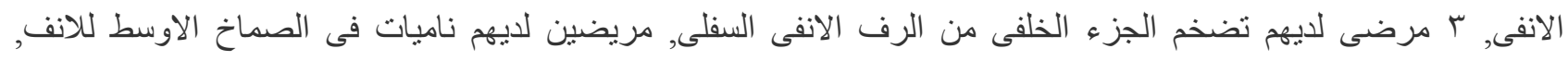

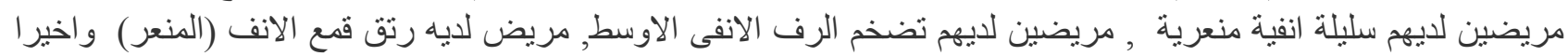
مريض لديه الورم الليفى النازف عند الإند اليافعين. الاستنتاج: نستنتج من هذه الدر اسة بأن ألمنظار ألأنفى هو وسيلة مهمة فى تقييم حالة الانف وبطانته وتحديد اسباب انسداد الانف

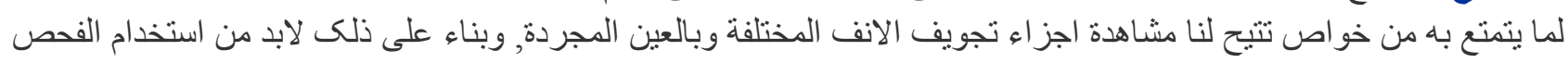

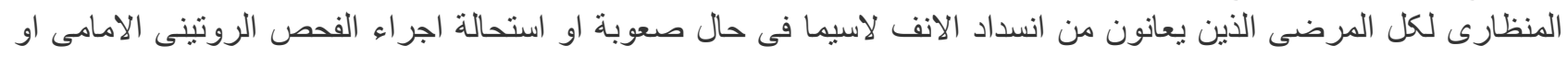

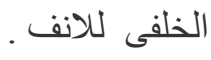

الكلمات المفتاحية : انسداد الانف ، حساسية الانف ، منظار الانف ، انحر اف الحاجز الانفى .

\section{INTRODUCTION}

$\mathrm{N}$ asal obstruction refers to situation of unease because of insufficient airflow. The most common nasal diseases which can cause nasal obstruction are allergic rhinitis and chronic rhinosinusitis in addition to structural alteration such as deviated nasal septum. Nasal obstruction is the reason for the most common ear, nose and throat (ENT) presentation in primary care and the it represents the most common reason for secondary care for ENT referrals. ${ }^{1}$

Nasal obstruction, as a symptom, typically has a benign course and this is the reason it does not receive adequate attention by the physicians as much as the tracking of diagnosis is concerned. Nasal obstruction affects negatively the life quality by creating unease, interference among smell and taste, social ostracism in some cases and life threating problems such as neoplasm which might be considered by the patient as a nasal obstruction at first. Therefore, it is a must that all physicians to attentional follow up the cause and the treatment of these patients ${ }^{2}$. The aim of the current study was to evaluate the endoscopic findings in patients with nasal obstruction which were missed by other methods of clinical examination.

\section{PATIENTS \& METHODS}

The present study was carried out on 75 adult patients aged 15- 69 years old, 43 males (57.3\%) and 32 females $(42.7 \%)$, presented to the Department of Otolaryngology in Al- Jumhoori Teaching Hospital from May 2014 to April 2015. They were all evaluated with anterior rhino-scopy, posterior rhino-scopy (only done for 7 patients who were cooperative and when possible), and nasal endoscopy. Ethical Approval no. 37 in 2015

\section{Inclusion Criteria}

Adult patients who presented with chief complaint of nasal obstruction were included. 


\section{Exclusion Criteria}

1-Patients younger than 15 years.

2- Patients with history of recent previous nasal or sinus surgery.

3- Patients with recent or previous maxillofacial trauma.

4- Patients have acute attack of common cold at time of examination.

5- Patients refuse the nasal endoscopic examination, or hesitated or anxious personality.

A detailed clinical history of the patients included in the study was considered giving a special attention for nasal symptoms. General and ENT examinations with diagnostic nasal endoscopic examination for anatomical and mucosal abnormalities were conducted. It identified redness, polyps, swelling, mucous, crusting and/ or pus deep inside the nasal cavity, septal deviation, spur, the state of turbinates, abnormal mass in the nasal cavity, and the nasopharynx, etc.

For twenty four patients, imaging of paranasal sinuses were done; (12) patients of them have plain lateral X-ray of the sinuses and postnasal space(water's view). CT scan of paranasal sinuses was conducted for 12 patients. For two of them, CT scan was done prior to nasal endoscopic examination. For the remaining patients, CT scan of the paranasal sinuses were required as the history of the the patients and the nasal endoscopic examination indicated a presence of sinus pathology or excluded the presence of pathology. When there is an indication for a sinus surgery, CT scans of the para-nasal sinuses are considered as an ultimate requirement as it becomes a "road map" for the anatomy of the patient which can be very variable.

The work-up of the patients included:-

1.Their detailed history, ENT examination especially nasal has been done in all cases

2. A diagnostic nasal endoscopy was conducted for all cases. The examination was conducted with either a rigid endoscope or flexible fiberoptic endoscope

Equipment: we used rigid nasal endoscopy with $4 \mathrm{~mm}$ diameter, 0 and 30 degrees endoscopes while endoscope of $2.7 \mathrm{~mm}$ diameter, 0 degree in cases where it was difficult to pass $4 \mathrm{~mm}$ endoscope owing to the narrowing of nasal cavity. The light was also provided with Karl Stroz source and a suction device to clear secretions. The fiberoptic endoscope was also used which has the benefit of being flexible and small in size. This means it provides accessibility to tight areas in different directions for better visualization for these tight areas.
Techniques: The patients were asked to sit upright in the examination chair so that the patient's head can be manipulated as needed to get better viewing of the nasopharynx or the olfactory cleft area.

Before nasal endoscopy, nasal cavities are prepared and sprayed with a nasal decongestant, such as oxymetazoline $0.1 \%$ with $2 \%$ xylocaine, Anesthetics is commonly applied either with a spray atomizer or directly on a cotton pledget. Before application, patients were checked if they have any medication allergies. The topical anesthetic was applied to the inferolateral surface of the middle turbinate, to the surface of the inferior turbinate, and to any other sites in which pressure can be exerted by insertion of the scope. The endoscopy was conducted for the three passes. Different structures were examined and the abnormalities that were found and noted.

- In the first Pass: we examined inferior meatus, floor of nose, post-nasal space, Eustachian tube orifice, and previous antrostomy.

- In the second Pass: we assessed lateral wall of nose which include agger nasi, polyps, accessory ostia and uncinate process, middle meatus which include hiatus semilunaris, bulla ethmoidalis, natural ostium and ground lamella, and middle turbinate abnormalities and variations.

- In the third Pass: we examined Superior turbinate / meatus, sphenoethmoidal recess and sphenoidal ostium

\section{RESULT}

1. Distribution of patients according to age groups:

The distribution of the patients according to their age; the larger group 19 patients is between (21$30)$ years, and the smallest 3 patients is between $(61-70)$ years. Males are 43 patients $(57.3 \%)$, and females are32 patients (42.6\%) Table 1 .

Table 1: Distribution of patients in terms of age groups \& gender.

\begin{tabular}{|l|l|l|l|}
\hline $\begin{array}{l}\text { Age } \\
\text { groups }\end{array}$ & $\begin{array}{l}\text { No. of patients } \\
\text { No. }(\%)\end{array}$ & $\begin{array}{l}\text { Males } \\
\text { No. }(\%)\end{array}$ & $\begin{array}{l}\text { Females } \\
\text { No. }(\%)\end{array}$ \\
\hline $\begin{array}{l}15-20 \\
\text { years }\end{array}$ & $\begin{array}{l}11 \text { patients } \\
(14.6 \%)\end{array}$ & $5(11.6 \%)$ & $6(18.8 \%)$ \\
\hline $\begin{array}{l}21-30 \\
\text { years }\end{array}$ & $\begin{array}{l}19 \text { patients } \\
(25.3 \%)\end{array}$ & $10(23.3 \%)$ & $9(28.1 \%)$ \\
\hline $\begin{array}{l}31-40 \\
\text { years }\end{array}$ & $\begin{array}{l}14 \text { patients } \\
(18.6 \%)\end{array}$ & $9(20.9 \%)$ & $5(15.6 \%)$ \\
\hline $\begin{array}{l}41-50 \\
\text { years }\end{array}$ & $\begin{array}{l}15 \text { patients } \\
(20 \%)\end{array}$ & $10(23.3 \%)$ & $5(15.6 \%)$ \\
\hline $\begin{array}{l}51-60 \\
\text { Years }\end{array}$ & $\begin{array}{l}10 \text { patients } \\
(13.3 \%)\end{array}$ & $6(13.9 \%)$ & $4(12.5 \%)$ \\
\hline $\begin{array}{l}61-70 \\
\text { years }\end{array}$ & 6 patients $(8 \%)$ & $3(7.0 \%)$ & $3(9.4 \%)$ \\
\hline Total & 75 patients & $43(57.3 \%)$ & $32(42.7 \%)$ \\
\hline
\end{tabular}


2. The endoscopic results.

We found septal deviation in 26 patients which represent about (34.6\%) as shown in table 2.

Table (2): The endoscopic findings of the patients.

\begin{tabular}{|l|l|l|l|}
\hline \multicolumn{2}{|l|}{ Endoscopic findings } & No. & $\%$ \\
\hline 1 & $\begin{array}{l}\text { Congested nasal mucosa } \\
\text { (edematous, swollen, red). }\end{array}$ & 40 & 53.3 \\
\hline 2 & Septal deviation . & 26 & 34.6 \\
\hline 3 & Inferior turbinate hypertrophy. & 18 & 24.0 \\
\hline 4 & $\begin{array}{l}\text { Pale swollen mucosa with } \\
\text { watery nasal secretion. }\end{array}$ & 14 & 18.6 \\
\hline 5 & Bilateral nasal polyposis. & 10 & 13.3 \\
\hline 6 & $\begin{array}{l}\text { Mucopurulent discharge from } \\
\text { middle meatus }\end{array}$ & 10 & 13.3 \\
\hline 7 & Post nasal drip. & 10 & 13.3 \\
\hline 8 & Crustation & 8 & 10.6 \\
\hline 9 & Adenoid hypertrophy & 5 & 6.6 \\
\hline 10 & Normal endoscopic findings. & 4 & 5.3 \\
\hline 11 & $\begin{array}{l}\text { Bluish tinged odematous } \\
\text { mucosa . }\end{array}$ & 3 & 4.0 \\
\hline 12 & $\begin{array}{l}\text { Unilateral nasal polyp originate } \\
\text { from middle meatus. }\end{array}$ & 3 & 4.0 \\
\hline 13 & $\begin{array}{l}\text { Hypertrophy of the posterior } \\
\text { end of inferior turbinate. }\end{array}$ & 3 & 4.0 \\
\hline 14 & Middle turbinate hypertrophy. & 2 & 2.6 \\
\hline 15 & Polypoidal mucosa. & 1 & 1.3 \\
\hline 16 & $\begin{array}{l}\text { Polypoidal nasal mass } \\
\text { occupying the nasal cavity. }\end{array}$ & 1 & 1.3 \\
\hline 17 & $\begin{array}{l}\text { Adhesion between inferior } \\
\text { turbinate with septum. }\end{array}$ & 1 & 1.3 \\
\hline 18 & $\begin{array}{l}\text { Pinkish, lobulated naso } \\
\text { pharyngeal mass. }\end{array}$ & 1 & 1.3 \\
\hline 19 & Choanal atresia. & 1 & 1.3 \\
\hline
\end{tabular}

The septal deviation is either the only finding or associated with other nasal cavity or post nasal pathology, which may be a complications of septal deviation, or as a separate pathology .

Table 3 shows that nasal polyposis was seen in 10 patients.

Table 3: Types of nasal polyposis causing nasal obstruction

\begin{tabular}{|l|l|l|}
\hline \multicolumn{2}{|l|}{ Findings } & No. \\
\hline 1 & $\begin{array}{l}\text { Bilateral nasal polyposis with } \\
\text { increased nasal secretion }\end{array}$ & $5(6.66 \%)$ \\
\hline 2 & Allergic fungal rhinosinusitis & $2(2.6 \%)$ \\
\hline 3 & $\begin{array}{l}\text { Bilateral nasal polyposis with } \\
\text { unilateral choanal atresia }\end{array}$ & $1(1.3 \%)$ \\
\hline 4 & $\begin{array}{l}\text { C shaped cartilage with bilateral } \\
\text { nasal polyposis }\end{array}$ & $2(2.6 \%)$ \\
\hline \multicolumn{2}{|l|}{ Total } & $10(100.0 \%)$ \\
\hline
\end{tabular}

*Another 4 patients had history of nasal obstruction throughout the year and few attacks of sneezing; their endoscopic findings were: bluish tinged nasal mucosa, one of them with watery nasal secretion (table 2), those were diagnosed as vasomotor rhinitis. One of these 4 patients was abusing the local nasal decongestant xylometazoline for more than 1 year to relief the obstruction resulted from vasomotor rhinitis which led to chronic nasal obstruction (rhinitis medicamentosa).

${ }^{*}$ Another 5 patients had drug history which may be correlated to their complaint of nasal obstruction. Two patients were on sildinafil for few months one of them was female with portal hypertension \& the $2^{\text {nd }}$ one was diabetic male. The $3^{\text {rd }}$ one was on tamsulosine for 2 years due to BPH. The $4^{\text {th }}$ patient of this group was hypertensive \& on atenolol for last 3 years, the last one used to take anxiolytic like alprazolam. Another patient in this group was pregnant was complaining from nasal obstruction but neither history nor endoscopic examination revealed an abnormality apart from mild congestion of nasal mucosa (hormonal rhinitis). Another patient had congested nasal mucosa (work as diacritics for $>10$ years) diagnosed as occupational rhinitis.

*Another group of patients included 7 patients $(9.3 \%)$ their endoscopic examination showed mucopurulent nasal secretion mainly from middle meatus \& congested mucosa (rhinosinusitis). Three of these patients had hypertrophy of the posterior end of the inferior turbinate in addition to the findings of rhinosinusitis \& one of them as we mentioned, had septal deviation, and one patient with middle turbinate hypertrophy.

${ }^{*}$ In this study 5 patients $(6.66 \%)$ were found to have adenoid hypertrophy (table 4).

Table 4: The endoscopic findings in patients with adenoid hypertrophy

\begin{tabular}{|l|l|l|}
\hline \multicolumn{2}{|l|}{ Findings } & Number \\
\hline 1 & $\begin{array}{l}\text { Posterior septal spur with adenoid } \\
\text { hypertrophy }\end{array}$ & 2 \\
\hline 2 & $\begin{array}{l}\text { Mucopurulent nasal secretions } \\
\text { with adenoid hypertrophy \& } \\
\text { postnasal drip }\end{array}$ & 2 \\
\hline 3 & $\begin{array}{l}\text { Adenoid hypertrophy with } \\
\text { postnasal drip. }\end{array}$ & 1 \\
\hline Total & 5 \\
\hline
\end{tabular}


${ }^{*}$ Four patients (5.3\%) had normal nasal endoscopy (table 2) but the history \& clinical examination revealed that 2 patients of them had history of adenoidectomy during childhood while at the time of examination we found that they have a narrow nose with high arched palate, the $3^{\text {rd }}$ was diagnosed to have alar collapse during inspiration while the $4^{\text {th }}$ patient had a history of nasal obstruction for 2 years but the history, clinical examination \& endoscopic examination showed nothing significant

*Another group of 3 patients (4\%), their chief complaints was unilateral nasal obstruction \& by nasal endoscopy we found a single unilateral nasal polyp originating from middle meatus \& extends posteriorly toward the choane (table 2), which was diagnosed as antrochoanal polyp.

${ }^{*}$ One patient $(1.3 \%)$ was complaining of unilateral nasal obstruction \& by the endoscopic examination we found a big polypoidal nasal mass filling the whole left nasal cavity. CT scan was requested and biopsy was taken and proved to be inverted papilloma and treated surgically.

*Another patient $(1.3 \%)$ who was 16 years old with history of nasal obstruction \& repeated attacks of epistaxis. By nasal endoscopy we found a big pinkish colored lobulated \& easily bled mass, occupying the nasopharynx which was removed by nasal surgery (lateral rhinotomy) \& was sent for histopathological study to confirm the diagnosis of juvenile angiofibroma (table 2).

${ }^{*}$ One patient $(1.3 \%)$ had history of nasal obstruction , 4 months after nasal surgery (septoplasty \& bilateral submucosal diathermy) \& by endocopic examination we found adhesion between the inferior turbinate \& nasal septum (synechia) (table 2).

*The final diagnosis for the patients depending on the endoscopic findings along with history, clinical examination \& radiological studies with percentage of male \& female involvements for each diagnosis were arranged in (table 5).

*Twenty patients (26.66\%) are found to suffer from some pathology diagnosed by endoscopy. These results were unavailable using anterior and posterior rinoscopy. (table 6)
Table5:The final diagnosis of the patients

\begin{tabular}{|l|l|l|l|l|}
\hline \multicolumn{2}{|c|}{ Final diagnosis } & No. (\%) & $\begin{array}{l}\text { Male } \\
\text { No. (\%) }\end{array}$ & $\begin{array}{l}\text { Female } \\
\text { No. (\%) }\end{array}$ \\
\hline 1 & $\begin{array}{l}\text { Septal } \\
\text { deviation }\end{array}$ & $19(25.3 \%)$ & $13(30.2 \%)$ & $6(18.8 \%)$ \\
\hline 2 & $\begin{array}{l}\text { Allergic } \\
\text { rhinitis }\end{array}$ & $12(16.0 \%)$ & $7(16.3 \%)$ & $5(15.6 \%)$ \\
\hline 3 & $\begin{array}{l}\text { Non allergic } \\
\text { rhinitis }\end{array}$ & $10(13.3 \%)$ & $3(7.0 \%)$ & $7(21.9 \%)$ \\
\hline 4 & Rhinosinusitis & $7(9.3 \%)$ & $4(9.3 \%)$ & $3(9.4 \%)$ \\
\hline 5 & $\begin{array}{l}\text { Bilateral nasal } \\
\text { polyposis }\end{array}$ & $6(8.0 \%)$ & $4(9.3 \%)$ & $2(6.3 \%)$ \\
\hline 6 & $\begin{array}{l}\text { Adenoid } \\
\text { hypertrophy }\end{array}$ & $5(6.6 \%)$ & $2(4.7 \%)$ & $3(9.4 \%)$ \\
\hline 7 & $\begin{array}{l}\text { Antrochaonal } \\
\text { polyp }\end{array}$ & $3(4.0 \%)$ & $2(4.7 \%)$ & $1(3.1 \%)$ \\
\hline 8 & $\begin{array}{l}\text { High arched } \\
\text { palate \& } \\
\text { narrow nose }\end{array}$ & $2(2.6 \%)$ & $1(2.3 \%)$ & $1(3.1 \%)$ \\
\hline 9 & $\begin{array}{l}\text { Allergicfungal } \\
\text { rhinosinusitis }\end{array}$ & $2(2.6 \%)$ & $1(2.3 \%)$ & $1(3.1 \%)$ \\
\hline 10 & $\begin{array}{l}\text { Septal } \\
\text { deviation with } \\
\text { allergic } \\
\text { rhinitis }\end{array}$ & $2(2.6 \%)$ & $0(0.0 \%)$ & $2(6.3 \%)$ \\
\hline 11 & $\begin{array}{l}\text { Septal } \\
\text { deviation with } \\
\text { nasal polyosis }\end{array}$ & $2(2.6 \%)$ & $1(2.3 \%)$ & $1(3.1 \%)$ \\
\hline 12 & $\begin{array}{l}\text { Alar collapse } \\
\text { Total }\end{array}$ & $1(1.3 \%)$ & $1(2.3 \%)$ & $0(0.0 \%)$ \\
\hline 13 & $\begin{array}{l}\text { Inverted } \\
\text { papilloma }\end{array}$ & $1(1.3 \%)$ & $1(2.3 \%)$ & $0(0.0 \%)$ \\
\hline 14 & $\begin{array}{l}\text { Juvenile } \\
\text { angiofibroma }\end{array}$ & $1(1.3 \%)$ & $1(2.3 \%)$ & $0(0.0 \%)$ \\
\hline 15 & $\begin{array}{l}\text { Synechia } \\
16\end{array}$ & $1(1.3 \%)$ & $1(2.3 \%)$ & $0(0.0 \%)$ \\
\hline Neurogenic & $1(1.3 \%)$ & $1(2.3 \%)$ & $0(0.0 \%)$ \\
\hline
\end{tabular}

Table 6: The findings seen on nasal endoscopy and missed on anterior and posterior rhino-scopy.

\begin{tabular}{|l|l|l|}
\hline \multicolumn{2}{|l|}{ The Results } & No. (\%) \\
\hline 1 & Adenoid hypertrophy & $5(25.0 \%)$ \\
\hline 2 & Spur in the floor Posteriorly & $4(20.0 \%)$ \\
\hline 3 & $\begin{array}{l}\text { Hypertrophied posterior end of } \\
\text { inferior turbinate }\end{array}$ & $3(15.0 \%)$ \\
\hline 4 & Middle meatus polyp & $2(10.0 \%)$ \\
\hline 5 & Antrochaonal polyp & $2(10.0 \%)$ \\
\hline 6 & Enlarged middle turbinate & $2(10.0 \%)$ \\
\hline 7 & Choanal atresia & $1(5.0 \%)$ \\
\hline 8 & Angiofibroma & $1(5.0 \%)$ \\
\hline Total & $20(100.0 \%)$ \\
\hline
\end{tabular}




\section{DISCUSSION}

The study was conducted on 75 adult patients with chief complaints of nasal obstruction,.Their ages ranged from 15- 69 years, 43 males $(57.3 \%)$ and 32 females $(42.7 \%)$, presented to the Department of Otolaryngology in Al- jumhoori Teaching Hospital from April 2014 to May 2015. To evaluate the nasal endoscopic findings necessary for proper diagnosis and treatment, by reporting the cause and site of obstruction.

Nasal obstruction or congestion seems to be a vague term with many synonyms in local, colloquial, and academic dialogue. Phrases include fullness, stuffiness, heaviness, discomfort, dripping, blocked nose, blocked airflow, blockage of nasal airflow, stuffed-up sinuses, sinus, chronic sinusitis, allergies, face pain, headache, sensation of reduced nasal patency, obstruction, restriction, increased nasal airflow resistance, and other terms. This implies that the term 'congestion' describes both subjective complains, and the outcomes of objective parameters by doctors ${ }^{3}$.

Sinonasal symptoms may be of limited value for diagnosis. Therefore, the findings of physical examination are more beneficial for diagnosis. Three methods are typically employed for most patients with long standing sinus or nasal complaints.

They are:

- anterior and posterior rhinoscopy

- nasal endoscopy

- CT scan of the nose and paranasal sinuses

These techniques reveal important information necessary for proper diagnosis and treatment. Interestingly, abnormalities have been detected on endoscopy or imaging can be present without symptoms ${ }^{4 .}$

The most common endoscopic findings of the patients were the congested nasal mucosa; (edematous, swollen, and red) (40) patients $(53.3 \%)$, the pathophysiology of the swollen edematous mucosa is due to:

1.Mucosal inflammation is typically the central pathophysiological mechanism that underlies many of the specific and interrelated factors which contribute to congestion, including increased venous engorgement, increased nasal secretions and tissue swelling/edema.

2. Allergic rhinitis, which cause nasal congestion, is primarily due to a combination of early and latephase of allergic inflammatory response ${ }^{5}$.
The second most common endoscopic findings of the patients was the septal deviation, found in (26) patients (34.6\%), Kishore et el in his study on 150 cases of nasal obstruction reported deviated nasal septum in 50 cases (37.53\%) Khalid et al reported $45 \%{ }^{2,6}$.

In the preset study we found the septal deviation a separate pathology or associated with other nasal mucosa pathology which may be a complication of septal deviation.

In a retrospective study, Gandomi et al. found a complete relief of symptoms in $10.6 \%$ of 334 septoplasties, $45.2 \%$ of which were satisfied with the outcome, $35.6 \%$ of which were partly satisfied and $19.2 \%$ of which expressed their dissatisfaction. In a follow up study after 24-64 months, patient satisfaction ranged from 63 to $70.5 \%$. In a longer follow up, Jessen et al. reported $26 \%$ of the patients free of symptoms nine years after surgery. Undoubtedly there are patients who benefit from a septoplasty for functional reasons ${ }^{7,8}$.

Ferguson stated that; the most common reason for persistent nasal obstruction which is not responding to nasal decongestants or medical therapy is a deviation of the nasal septum. Most of the times internal deformity of one nose obstructing airflow coexists with turbinate hypertrophy in the other side. So, septal correction frequently requires simultaneous correction of the hypertrophied inferior turbinate. In addition to septal deflections at the nasal valve, the nose sometimes collapses at the valve owing to weakness of the lateral cartilage. Correction requires a lateral nasal batten. A previous rhinoplasty with excessive resection of the lower lateral cartilages is risky for nasal valve collapse ${ }^{9}$.

Inferior turbinate hypertrophy were found in 18 patients $24 \%$, this may be due to allergic rhinitis, non allergic rhinitis, rhinosinusitis, and with compensatory inferior turbinate hypertrophy in contralateral side associated with septal deviation.

Grymer had discussed this condition; turbinates mucosal swelling is typically part of the physiologic vascular changes, while the osseous part of both the middle and inferior turbinates may be enlarged, as a developmental process on the wider side of the nose, contralateral to marked septal deviations. This phenomenon is known as "compensatory turbinate hypertrophy') ${ }^{10}$. There were 14 patients with Pale swollen mucosa (allergic rhinitis), most of them were examined during spring (April 2015), the numbers of patient are variable along the year, it depends on the season the patients attend the examination, Naclerio reported in his study; the distribution of allergic rhinitis is expanding all over the world, occurring in $10 \%$ to $30 \%$ in adults and up to $45 \%$ of children. About $50 \%$ of patients with 
allergic rhinitis show symptoms for more than 4 months per year, and nasal congestion is mostly the main symptom ${ }^{5}$.

Subjects reported complains of nasal fullness with allergic rhinitis, $40 \%$ of them were severe, $35 \%$ of them were moderate and $25 \%$ of them were mild.Fullness was the apparent disturbing symptom in $50-78 \%$ of patients subject to study. ${ }^{3}$

Bilateral nasal polyposis (BNP) was found in 10 patients $(13.3 \%)$ which cause bilateral nasal obstruction, Gupta et el reported on his study that from 80 cases examined only 19 patients showed polyposis on anterior rhinoscopy while 29 patients had been diagnosed with nasal polyposis on endoscopy ${ }^{11}$.

Three patients have antrochaonal polyp (ACP) and had been diagnosed as the cause of unilateral permanent nasal obstruction, 2 of them were only seen by $1^{\text {st }}$ pass of rigid nasal endoscopy extending towards the choane while the $3^{\text {rd }}$ one was big enough to be seen by anterior rhinoscopy.

Unlike allergic rhinitis, in patients with non allergic rhinitis, there were no definite diagnostic tests for non allergic rhinitis, and diagnosis was done on clinical basis in the absence of allergy (negative allergy testing) ${ }^{12}$.

Naclerio stated that non allergic rhinitis (non $\lg \mathrm{E}$ mediated ) includes infectious, vasomotor , hormonal rhinitis (in pregnancy and menstruation) and nonallergic rhinitis with eosinophilia syndrome (NARES), ${ }^{13}$.

Jareoncharasi et al. did nasal endoscopy to 83 patients with perennial allergic rhinitis for evaluating anatomical variations of the nose and to discover the relation between the patients complains and the endoscopic findings. The results showed that $95.2 \%$ of patients had endoscopic abnormal findings or variations which were septal deviation $(72.3 \%)$, middle turbinate abnormalities $(49.4 \%)$ narrow entrance into the frontal recess $(30.1 \%)$, septal spur $(25.5 \%)$, inferior turbinate hypertrophy (10.8\%), abnormal uncinate process (9.6\%), abnormal ethmoid bullae $(7.2)$ and enlargement of agar nasi cells $(2.4 \%)^{14}$.

Five patients $(6.6 \%)$, their endoscopic findings were adenoid hypertrophy presented with nasal obstruction, snoring and post nasal drip with other symptom of rhinosinusitis (table 4). Two patients had history of adenoidectomy in childhood while the other (3) did not have ${ }^{15}$.

Adults adenoid hypertrophy occur secondary to chronic or recurrent infection or anatomical disturbances that result in chronic inflammation and persistence of nasopharyngeal tonsil. Finklelstein et al found the presence of obstructive adenoids in $30 \%$ of chronic smoker ${ }^{16}$.
Abou Elhamd 2006 reported on his study on the cause and site of nasal obstruction in adult that $46 \%$ of the cases had posterior nasal obstruction, $43.5 \%$ owing to post- choanal lesions (mainly adenoid), 33\% owing to pre- choanal lesions (mainly choanal polyps) and $23.5 \%$ owing to choanal lesions (mainly choanal adenoid) ${ }^{17}$.

Hamad 2014 et al reported the incident of adenoid hypertrophy on (140) adult patients complaining of nasal obstruction in (24) patients ${ }^{6}$.

Ranjan showed that $(21 \%)$ of adult nasal obstruction is due to adenoid hypertrophy. Nasal obstruction and snoring were often caused by adenoid enlargement in adults ${ }^{18-21}$.

A group of 4 patients $5.3 \%$ complaining from nasal obstruction with almost normal endoscopic findings \& variable different diagnosis for the cause of obstruction.

- Two patients had narrow nose \& high arched palate with history of adenoid hypertrophy \& adenoidectomy during childhood.

- The $3^{\text {rd }}$ patients were also diagnosed clinicaly as alar collapse.

- The $4^{\text {th }}$ \& last patients in this group nothing significant was found in the history \& examination which may lead us to ask weather this is objective or subjective nasal obstruction; may be due to Modulation of sensory perception.

The nostrils shape and the tip projection are closely related to the geometry of the vestibule and the dimensions of the valve area and as such are signs related to functional problems ${ }^{22}$.

Internal nasal valve is the narrowest part of the nose, hence a few millimeters deviation at this point can cause significant obstruction. By lateral traction on the cheek opens the nasal valve (Cottle maneuver); relief with this maneuver indicates the obstruction at the level of nasal valve area ${ }^{9}$.

It is worth mentioning that typical symptoms of rhinitis can be the result of neural mechanisms verifiable mucosal abnormality. on the contrary, patients with complete turbinectomy "empty nose" may yet suffer from the perception of nasal congestion. ${ }^{5}$.

Some individuals might have decreased airflow receptor activity, and therefore, even if their airways are unrestricted, they may feel that nasal airflow is not adequate ${ }^{13}$.

In the present study 20 cases (26.66\%) are found to suffer from some pathology diagnosed on endoscopy. These results were not reached through using anterior and posterior rhino-scopy. (table 6). 
Kishore reported that 56 cases (37.33\%) were found to have pathologies seen on endoscopy. These findings were skipped on anterior and posterior rhino-scopy ${ }^{2}$.

Lawrason \& Meyers applied rigid nasal endoscopy on patients with sinonasal complaint; they found nasal problems in about $40 \%$ of patients who showed almost normal examination by anterior rhino-scopy ${ }^{23}$. Also Levine \& Cleveland in their study on 150 cases with chronic nasal and sinus symptoms, the nasal pathology were found in 58 patients(38.70\%) with the use of nasal endoscope which was not seen by anterior and posterior rhinoscopic examination. ${ }^{24}$

\section{CONCLUSION}

Nasal endoscopy has been used as an objective diagnostic tool as part of sinonasal examination. In current study the use of diagnostic nasal endoscopy is recommended routinely in all cases complaining of nasal obstruction, moreover it may help in decreasing the need to use computed tomography $(\mathrm{CT})$, hence reducing the cost and the exposure to radiation and prevent the patients from unneeded surgical procedure. It can be both available and affordable. The images of the endoscope could also be taken and kept for documentation.

\section{REFERENCES}

1.Chia-Hung Li, Anika Kaura, Calvin Tan, Katherine Whitcroft, Terence S. Leung, Peter Andrews. Diagnosing nasal obstruction and its common causes using the nasal acoustic device: A pilot study. Laryngoscope Investigative Otolaryngology. 2020; 5(5): 796-806. DOI: $10.1002 /$ lio2.445

2.Kishore K., Vidushi Badial, Dinesh Luthra, Padam Singh Jamwal. Pattern of Abnormal Findings in Adult with Nasal Obstruction on Rhinoscopy and Nasal Endoscopy. Department of ENT, Govt Medical College Jammu, J\&KIndia. July - September 2012; 14(3): 125-128. Corpus ID: 55942301

3.James N., Baraniuk. Subjective Nasal Fullness and Objective Congestion. Proceeding Of the American Thoracic Society. 2011 Mar 1; 8(1): 62-69. doi: 10.1513/pats.201006-042RN

4.Dharambir S Sethi. Diagnosis of Nasal \& Sinus Disorders [Online]. 2012 April 19 [cited 2012 June 13]; Available from URL:http://www. drsethi.com.sg

5.Robert M Naclerio, Claus Bachert, James N Baraniuk. Pathophysiology of nasal congestion.
Int J Gen Med. 2010; 3: 47-57. doi: $\underline{10.2147}$ lijgm .s8088

6. Hamad KD , Alhamadani R , Jassim AA. Adenoid Hypertrophy in Adults and Nasal Obstruction.KCMJ 2014; 10 (1) : 1-3.

7. Gandomi B, Bayat A, Kazemei T. Outcomes of septoplasty in young adults: the nasal obstruction septoplasty effectiveness study. May-June 2010; 31(3): 189-192.DOI: $\underline{10.1016}$ i.am joto.2009.02.023

8. Jessen N. M., Ivarsson A, Malan L. Nasal airway resistance and symptoms after functional septoplasty. Clinical otolaryngololgy and allied sciences. 1989; 14: 231-234. Doi:10.1111/j.1365-2273.1989.tb003 66.x.

9.Berrylin J. Ferguson. Surgical Correction of Nasal Obstruction. In: Myers Operative Otolaryngology Head and Neck Surgery 2nd edition. Copyright (C) 2009 Elsevier Inc. DDC 617.51059

10. Luisa F. Grymer. The management of enlarged turbinates. In: Scott-Brawn's Otorhinolaryngology, Head and Neck Surgery 7th edition. Vol 2. 2008 Edward Arnold (Publishers) Ltd. ISBN: 9780340808931.

11. Gupta Y, Sinha R. Role of Anterior Rhinoscopy, Nasal Endoscopy and Computed Tomography in the Detection of Early Polyposis of Nasal Mucosa. Int J Adv Health Sci 2014; 1(2): 11-16. Corpus ID: 212531584

12. Wallace DV, Dykewicz, Bernstein DI, et al. The diagnosis and management of rhinitis: an updated practice parameter. J Allergy Clin Immunol. 2008; 122(Suppl 2):S1-S84. Doi: 10.1016/j.jaci.2008.06.003.

13. Stephanie A. Joe, Sundip Patel. Non allergic Rhinitis. In: Cummings Otolaryngology Head \& Neck Surgery $5^{\text {th }}$ edition. 2010 MOSBY Elsevier. ISBN: 978-0-323-08563-2

14. Jareoncharasi $P$, Thitadilok $V$, Bunchag $B$ et al. Nasal endoscopic findings in patients with perennial allergic rhinitis. Asian Pacific J Allergy Immunol. 1999; $17 \quad$ (4): $261-267$. PMID: 10698465

15. Pearl AJ, Maoukian JJ: Adeoidectomy: Indirect visualization of choanal adenoids./ Otolaryngology $1994 ; \quad 23: 221-224$ PMID : 8064966

16. Finkelstein Y, Malik Z, Kopolovic J, Bernheim $\mathrm{J}$, Djaldett $\mathrm{M}$, Ophin D. Characterization of 
smoking-induced nasopharyngeal lymphoid hyperplasia. Laryngoscope. 1997; 107: 16351642. doi.org/10.1097/00005537-19971200000011

17. Kamal al- din A. Abou Elhamd, Ramadan H. Sayed. Assesment of nasal obstruction with flexible nasal endoscopy. Suadi Med J. 2006; 27 (12): 1850-1852. PMID: 17143363

18. Peter J Robb. The adenoid and adenoidectomy In: Scott-Brawn's Otorhinolaryngology, Head and Neck Surgery 7th edition. Vol 2. 2008 Edward Arnold (Publishers) Ltd. ISBN: 9780340808931.

19. Karodpati N, Shinde V, Deogawkar S, Ghate G. Adenoid Hypertrophy in Adults - A Myth or Reality. Webmed Central 2013 ; 4(3): WMC004079.https://doi.org/10.9754/journal.wmc .2013 .004079

20. Orji F, Okorafor I, Ofoegbu V, llechukwu I.A. Obstructive Adenoid Hypertrophy in the Adult): A Case Report Orient Journal of Medicine. Journal Home. 2009; 21: 1-4. DOI: 10.4314/ojm.v21i14.54470

21. Rout MR, Mohanty D, Vijaylaxmi Y, Bobba K, Metta C . Adenoid Hypertrophy in Adults: A case Series. Indian Journal of Otolaryngology and Head \& Neck Surgery. July 2013; 65(3): 269-274. Doi: $10.1007 /$ s12070-012-0549-y

22. Adriaan $F$ Van Olphen. The septum; Hodder Arnold; Scott-Brown's Otorhinolaryngology, Head and Neck Surgery, UK, Oxford, Blackwell Publishing; 2008. Volume 2. 7th ed.; p. 15691581. ISBN: 9780340808931.

23. Lawrason AE, Meyers AD. Rigid nasal endoscopy in patients with sinonasal complaints. (Updated April 20, 2012). Medscape Reference. Available at: http//.www .emedicine.medscape.com / article 1890.

24. Levine HL. The office diagnosis of nasal and sinus disorder using rigid nasal endoscopy. Otolaryngology, Head \& Neck Surgery.1990;102: 370-373. Doi: $10.1177 / 019459989010200411$. 